\title{
Contentious Belonging
}

The Place of Minorities in Indonesia

\author{
EDITED BY \\ GREG FEALY - RONIT RICCI
}


First published in Singapore in 2019 by

ISEAS Publishing

30 Heng Mui Keng Terrace

Singapore 119614

E-mail:publish@iseas.edu.sg

Website: http://bookshop.iseas.edu.sg

All rights reserved. No part of this publication may be reproduced, translated, stored in a retrieval system, or transmitted in any form or by any means, electronic, mechanical, photocopying, recording or otherwise, without the prior permission of the ISEAS - Yusof Ishak Institute.

(C) 2019 ISEAS - Yusof Ishak Institute, Singapore

The responsibility for facts and opinions in this publication rests exclusively with the authors and their interpretations do not necessarily reflect the views or the policy of the Institute or its supporters.

\section{ISEAS Library Cataloguing-in-Publication Data}

Contentious Belonging : The Place of Minorities in Indonesia / edited by Greg Fealy and Ronit Ricci.

“... an outcome of the Indonesia Update Conference held in Canberra on 14-15 September 2018."

1. Minorities - Indonesia.

2. Minorities - Civil rights - Indonesia.

3. Indonesia-Social conditions.

4. Indonesia-Ethnic relations.

5. Minorities - Indonesia-Public opinion.

6. People with disabilities - Indonesia.

7. Sexual minorities - Indonesia.

8. Religious tolerance-Indonesia.

I. Fealy, Greg, editor.

II. Ricci, Ronit, editor.

III. Indonesia Update Conference (36th : 2018 : Australian National University)

DS644.4 I41 $2018 \quad 2019$

ISBN 978-981-4843-46-1 (soft cover)

ISBN 978-981-4843-49-2 (hard cover)

ISBN 978-981-4843-47-8 (ebook, PDF)

Cover photo: Wayang puppets on sale at an antiques market in Jakarta Photo by Peter Adams Photography Pte Ltd / Alamy Stock Photo

Edited and typeset by Beth Thomson, Japan Online, Canberra Indexed by Angela Grant, Sydney

Printed in Singapore by Markono Print Media Pte Ltd 
Contentious Belonging 
The ANU Indonesia Project, a leading international centre of research and graduate training on the Indonesian economy and society, is housed in the Crawford School of Public Policy's Arndt-Corden Department of Economics. The Crawford School is part of ANU College of Asia and the Pacific at The Australian National University (ANU). Established in 1965 in response to profound changes in the Indonesian economic and political landscapes, the ANU Indonesia Project has grown from a small group of Indonesia-focused economists into an interdisciplinary research centre well known and respected across the world. Funded by ANU and the Australian Department of Foreign Affairs and Trade, the ANU Indonesia Project monitors and analyses recent developments in Indonesia; informs the Australian and Indonesian governments, business and the wider community about those developments and about future prospects; stimulates research on the Indonesian economy; and publishes the respected Bulletin of Indonesian Economic Studies.

ANU College of Asia and the Pacific's Department of Political and Social Change focuses on domestic politics, social processes and state-society relationships in Asia and the Pacific, and has a long-established interest in Indonesia.

Together with the Department of Political and Social Change, the ANU Indonesia Project holds the annual Indonesia Update conference, which offers an overview of recent economic and political developments and devotes attention to a significant theme in Indonesia's development. The Bulletin of Indonesian Economic Studies publishes the conference's economic and political overviews, while the edited papers related to the conference theme are published in the Indonesia Update Series.

The ISEAS - Yusof Ishak Institute (formerly Institute of Southeast Asian Studies) is an autonomous organization established in 1968. It is a regional centre dedicated to the study of socio-political, security, and economic trends and developments in Southeast Asia and its wider geostrategic and economic environment. The Institute's research programmes are grouped under Regional Economic Studies (RES), Regional Strategic and Political Studies (RSPS), and Regional Social and Cultural Studies (RSCS). The Institute is also home to the ASEAN Studies Centre (ASC), the Nalanda-Sriwijaya Centre (NSC) and the Singapore APEC Study Centre.

ISEAS Publishing, an established academic press, has issued more than 2,000 books and journals. It is the largest scholarly publisher of research about Southeast Asia from within the region. ISEAS Publishing works with many other academic and trade publishers and distributors to disseminate important research and analyses from and about Southeast Asia to the rest of the world. 